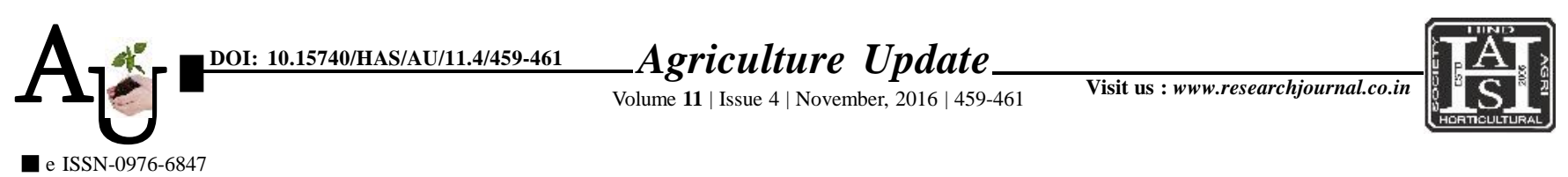

\title{
Research Note: To study the knowledge and adoption about recommended package of practices of summer groundnut
}

\section{D.B. RATHOD AND J.H. GAIKWAD}

Article Chronicle:

Received :

05.10.2016;

Accepted :

30.10 .2016

KEY WoRds :

Knowledge,

Adoption,

Summer

groundnut
SUMMARY : Groundnut is the single largest source of edible oils in India and constitutes roughly about 50 per cent of the total oilseeds production. India occupies the first place in acreage and second in production of groundnut. The list of summer groundnut growing villages of Rahuri, Sangamner, Akole, Rahata, Newasa and Shrirampur tehsils was obtained from taluka Krishi Adhikari. Two villages from each tehsil that is 12 villages were selected for the study on the basis of area under summer groundnut crop. A total of 10 summer groundnut growers from each village were selected randomly on the basis of area under summer groundnut crop. Hence, in 6 tehsils, 12 villages and 120 respondents were selected for the present study. It is concluded that about 60.84 per cent respondents had medium knowledge level, followed by 22.50 per cent respondents had low knowledge level and 16.66 per cent respondent summer groundnut growers had high knowledge level. And 65.83 per cent respondents had medium adoption level, followed by 18.34 per cent respondents had low adoption level and 15.83 per cent respondent summer groundnut growers had high adoption level.

How to cite this article : Rathod, D.B. and Gaikwad, J.H. (2016). To study the knowledge and adoption about recommended package of practices of summer groundnut. Agric. Update, 11(4): 459-461; DOI : 10.15740/HAS/ AU/11.4/459-461.

\section{D.B. RATHOD}

Department of Extension Education, Mahatma Phule Krishi Vidyapeeth, Rahuri, AHMEDNAGAR (M.S.) INDIA

See end of the article for authors' affiliations 